\title{
Preparation and reactivity of some stable nitrile oxides and nitrones
}

\author{
Paul W. Groundwater, ${ }^{a *}$ Miklós Nyerges, ${ }^{\mathrm{b}}$ Imre Fejes, ${ }^{\mathrm{b}}$ David E. Hibbs,

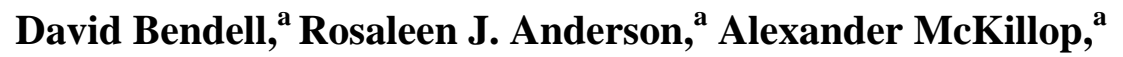 \\ Toqir Sharif, ${ }^{\mathrm{c}}$ and Weimin $\mathrm{Zhang}^{\mathrm{a}}$ \\ ${ }^{a}$ Institute of Pharmacy and Chemistry, \\ University of Sunderland, Sunderland,UK SR1 3SD \\ ${ }^{b}$ Research Group of the Hungarian Academy of Sciences, \\ Department of Organic Chemical Technology, Technical University of Budapest, \\ H-1521 Budapest P.O. Box 2, Hungary \\ ${ }^{c}$ Department of Chemistry, Cardiff University, \\ P.O. Box 912, Cardiff, UK CF1 3TB \\ E-mail: Paul.Groundwater@sunderland.ac.uk \\ To Otto on the occasion of his $65^{\text {th }}$ birthday \\ (received 10 May 00; accepted 03 Oct 00; published on the web 11 Oct 00)
}

\begin{abstract}
a,b;g,d-Unsaturated nitrile oxides 6, 13 have been prepared from the corresponding aldehydes via sequential oxime formation, chlorination, and dehydrochlorination. These nitrile oxides show unexpected stability, presumably due to delocalisation, and can be isolated. 2,6-Diphenylbenzonitrile oxide $13 \mathrm{~b}$ was particularly stable and a single crystal X-ray structure was obtained. 3,3-Diphenylpropenitrile oxide 6 was also isolated but could be dimerized, to give a 1,4,2,5-dioxadiazine 7 or furoxan 8, via slight modifications to the conditions employed. The corresponding nitrones 14, 17 have also been prepared, via the reaction of the a,b;g,d-unsaturated aldehydes 10a,b with substituted hydroxylamines, isolated and trapped.
\end{abstract}

Keywords: Nitrile oxides, nitrones, dimerization, X-ray crystal structure

\section{Introduction}


The majority of nitrile oxides, like the other classes of nitrilium betaine 1,3-dipoles, are chemically unstable and undergo dimerization to either 1,4,2,5-dioxadiazines or furoxans. ${ }^{1}$ Relatively stable nitrile oxides can be obtained as a result of steric shielding of the nitrile oxide moiety, ${ }^{2}$ e.g. 4-substituted-2,6-dimethylbenzonitrile oxides 1 , or by electrostatic (donor-acceptor) interactions, ${ }^{3}$ e.g. methylsulphonylthiophenecarbonitrile oxide 2. Stabilization by steric shielding produces nitrile oxides which are unreactive in both the solid and solution states, whilst stabilization due to electrostatic interactions generally gives nitrile oxides which are stable in the solid state, but which are reactive in solution. This latter class of nitrile oxides dimerize, or react with dipolarophiles, in solution.
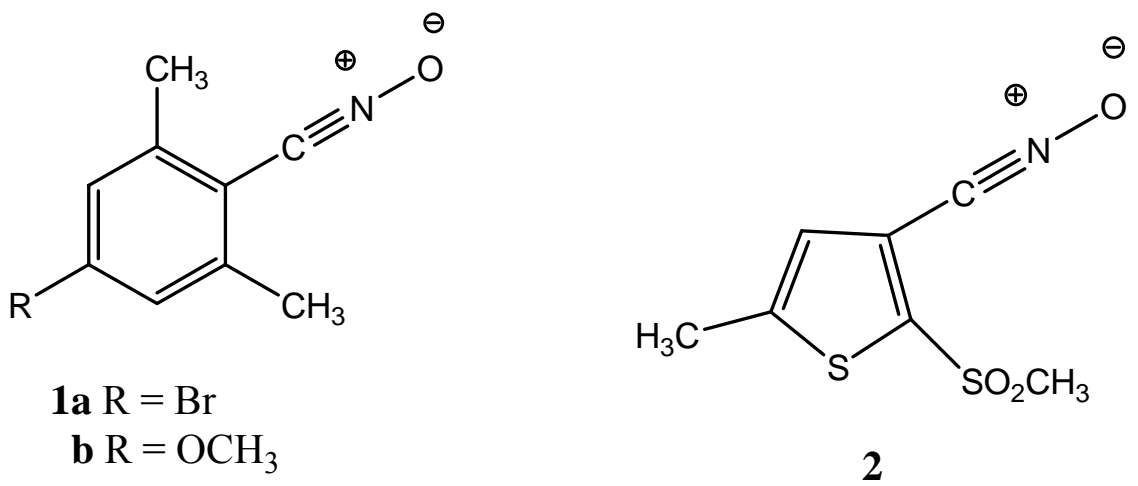

Nitrones are reactive 1,3-dipoles of the allyl class which are also usually generated in situ. Nitrones have proved to be very useful tools in the construction of structurally complex molecules, usually allowing a high degree of diastereocontrol. In this context, both the nitrone [3+2] cycloaddition to alkenes ${ }^{4}$ and the alkylation of nitrones by organometallic reagents ${ }^{5}$ have been extensively developed and have become reliable synthetic procedures. In addition, nitrones are useful spin trap reagents, and are thus widely employed in biological systems. ${ }^{6}$

We wish to report here the preparation of some nitrile oxides and nitrones with a,b;g,d-unsaturation, which show unexpected stability in the solid state, presumably due to resonance stabilization, but which undergo dimerization, or can be trapped by dipolarophiles, in solution. The intramolecular reactivity of C-(1-buten-3-ynyl)-nitrones has been studied in detail by Eberbach, ${ }^{7}$ but no data are available on the reactivity of the analogous C-(1,3-butadienyl)-derivatives.

\section{Results and Discussion}


The nitrile oxide 6 was prepared via the corresponding aldoxime $4,{ }^{8}$ generated from bphenylcinnamaldehyde 3 and hydroxylamine hydrochloride, in the presence of a base. The oxime 4 was obtained as a mixture of syn and anti forms and was used in the next step without further purification. Conversion to the corresponding nitrile oxide 6 was achieved by chlorination with $\mathrm{N}$-chlorosuccinimide in DMF to give the hydroximoyl chloride 5 followed by base-catalysed dehydrochlorination, Scheme $1 .^{9}$

When the hydroximoyl chloride was prepared at $35^{\circ} \mathrm{C}$, in the absence of base, the dioxadiazine 7 was obtained, whereas at $40^{\circ} \mathrm{C}$, in the presence of triethylamine, dimerisation afforded the furoxan 8 . The two products were characterised by high resolution mass spectrometry and NMR spectroscopy. The proton NMR spectrum of dioxadiazine 7 shows a singlet for the equivalent alkene protons, at d6.49, whilst that of the furoxan 8 shows $1 \mathrm{H}$ singlets at $\mathrm{d} 6.59$ and $\mathrm{d} 6.74$.

When the reaction was repeated, and the aldoxime chlorinated at $40^{\circ} \mathrm{C}$, followed by additional stirring at $25^{\circ} \mathrm{C}$ overnight, with subsequent dehydrochlorination by treatment with triethylamine and standard work-up, 3,3-diphenylpropenitrile oxide 6 was isolated as a stable product. The IR spectrum shows an intense peak at $2287 \mathrm{~cm}^{-}$

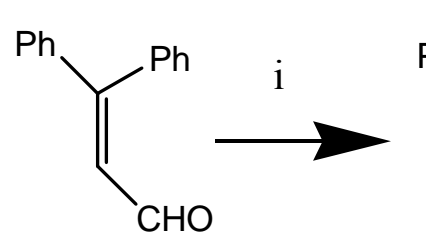

3
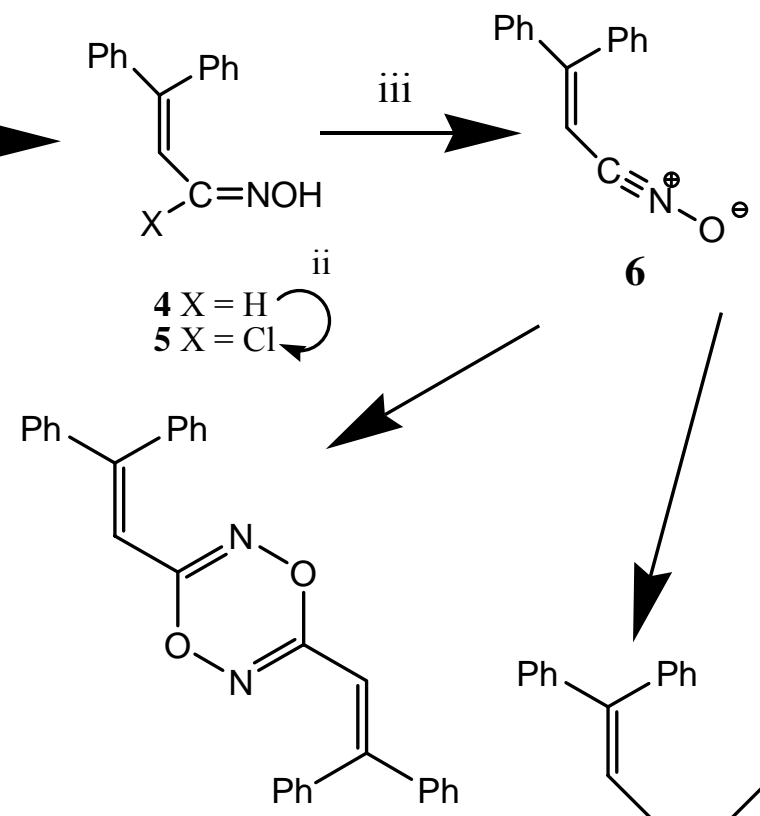

7

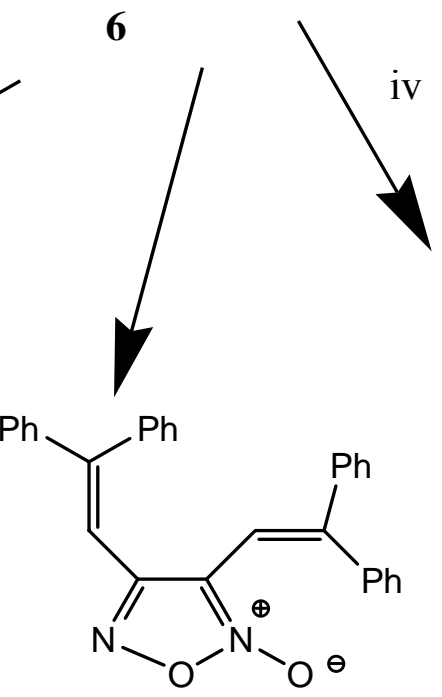

8

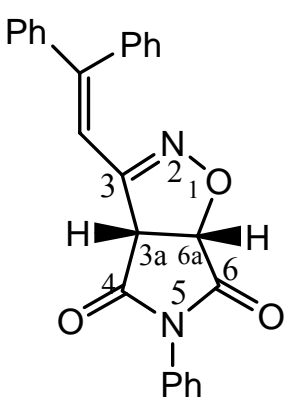

9 
Scheme 1. Reagents and conditions; $\mathrm{I}, \mathrm{NH}_{2} \mathrm{OH}, \mathrm{NaOH}, \mathrm{EtOH}, \mathrm{H}_{2} \mathrm{O}$, reflux, $30 \mathrm{~min}$, $78 \%$; ii, NCS, DMF; iii, $\mathrm{Et}_{3} \mathrm{~N}, \mathrm{Et}_{2} \mathrm{O}$; iv, $\mathrm{N}$-phenylmaleimide, $\mathrm{Et}_{2} \mathrm{O}$.

for $\mathrm{Cthree}=\mathrm{N}^{+}-\mathrm{O}^{-}$and the proton NMR spectrum shows a singlet at $\mathrm{d} 5.76$. The structure was confirmed by high resolution mass spectrometry. This nitrile oxide is stable when stored at $0 \mathrm{C}$, presumably due to the extended conjugation in this system, Figure 1, giving rise to resonance stabilization. The reactivity of this stable nitrile oxide was then investigated by generation in the presence of $N$-phenylmaleimide to give the cycloadduct 9 in excellent yield, Scheme 1 .

In the same way, nitrile oxides 13 were generated from the corresponding aldehydes 10 via oxime 11 formation, chlorination to the hydroximoyl chlorides 12, and dehydrochlorination with base, Scheme 2. 2,6-Diphenylbenzonitrile oxide 13b was obtained as a crystalline solid and is also stable upon storage. In this case, the stability presumably arises from both resonance stabilization and steric shielding of the nitrile oxide group. No products from the dimerisation of these nitrile oxides were obtained.

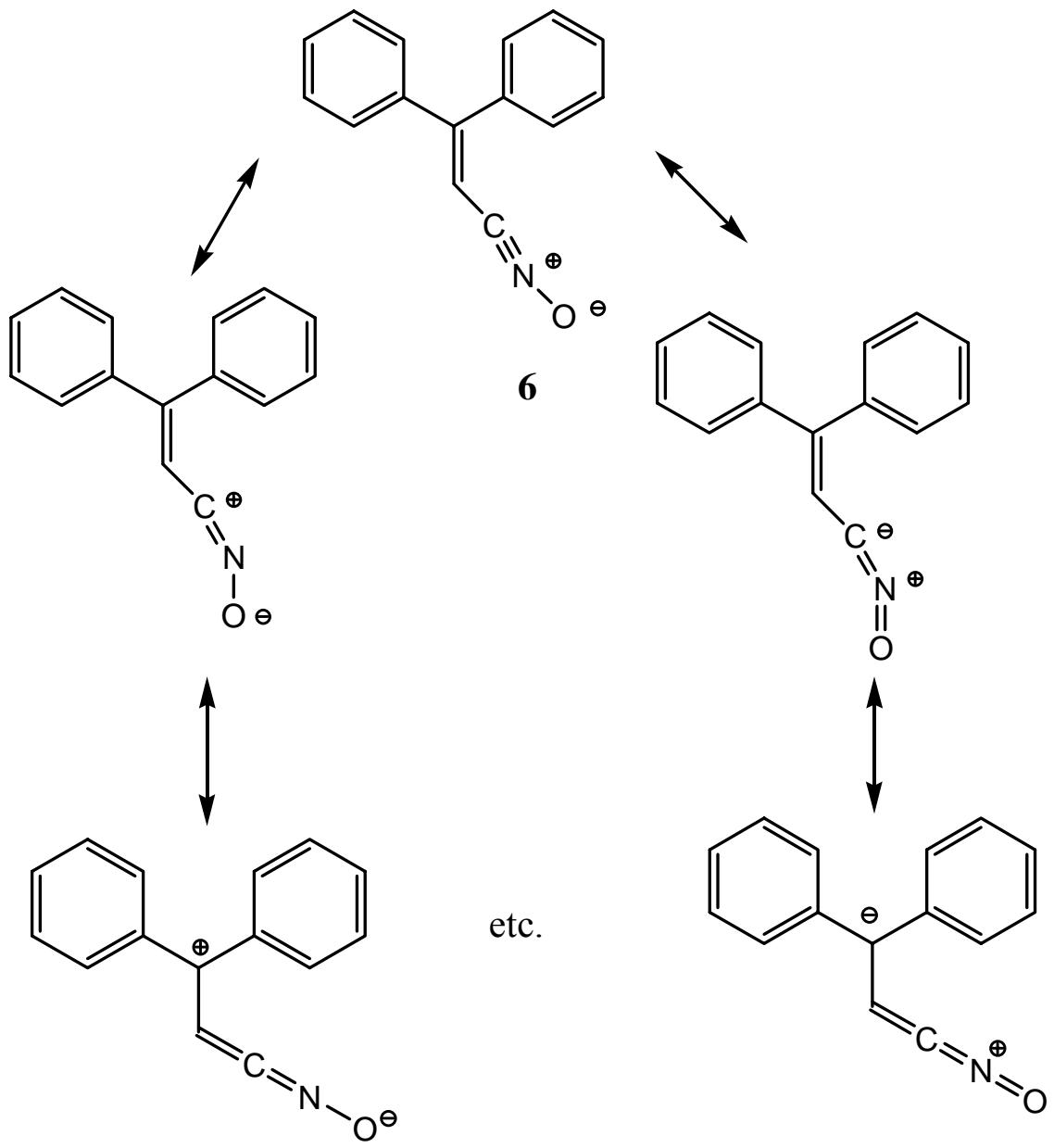




\section{Figure 1}

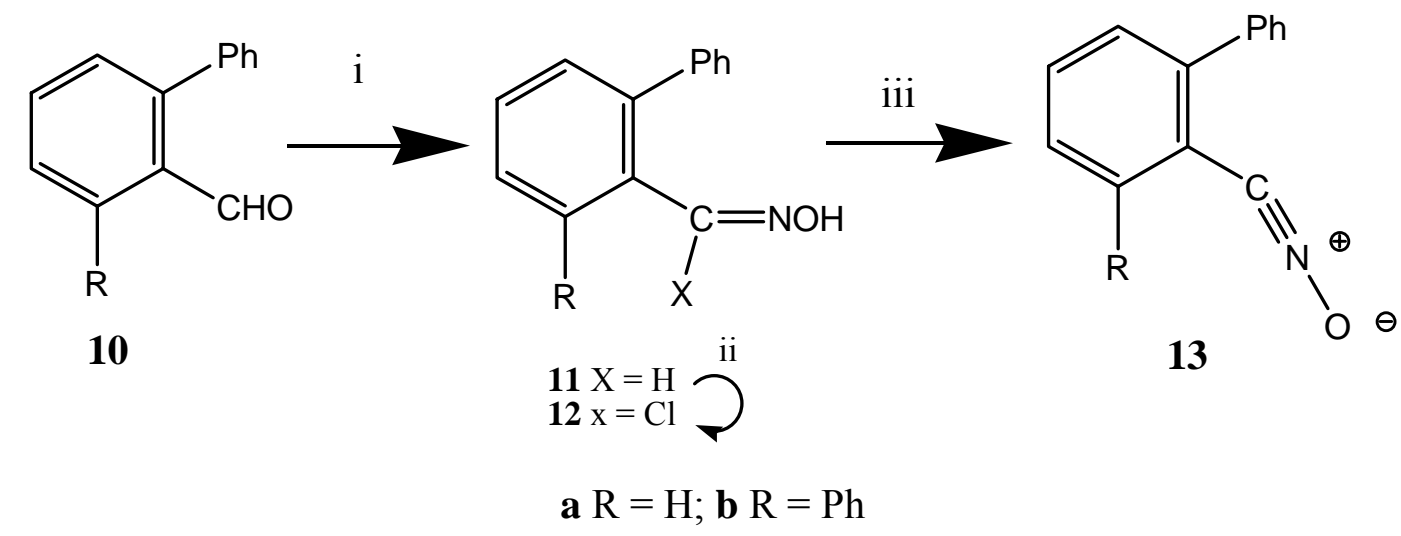

Scheme 2. Reagents and conditions; I, $\mathrm{NH}_{2} \mathrm{OH}, \mathrm{NaOH}, \mathrm{EtOH}, \mathrm{H}_{2} \mathrm{O}$, reflux, 30 min, $78 \%$; ii, NCS, DMF; iii, $\mathrm{Et}_{3} \mathrm{~N}, \mathrm{Et}_{2} \mathrm{O}$.

A single crystal X-ray structure of this nitrile oxide was obtained, the key feature of which is the linear nitrile oxide group with a bond angle $\mathrm{DC}^{\circ} \mathrm{N}-\mathrm{O}$ of $179.4^{\circ}$, Figure 2.

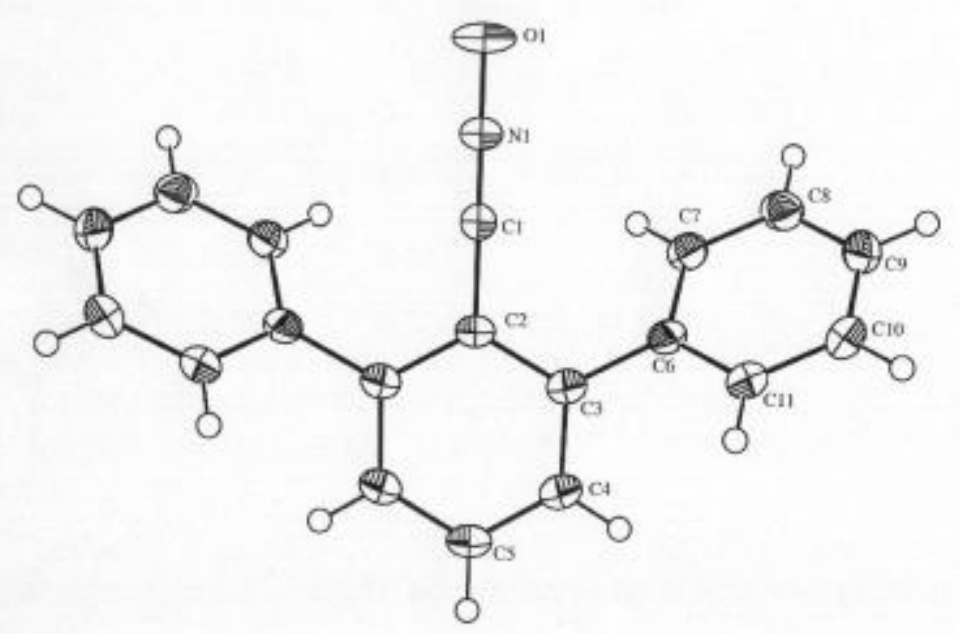




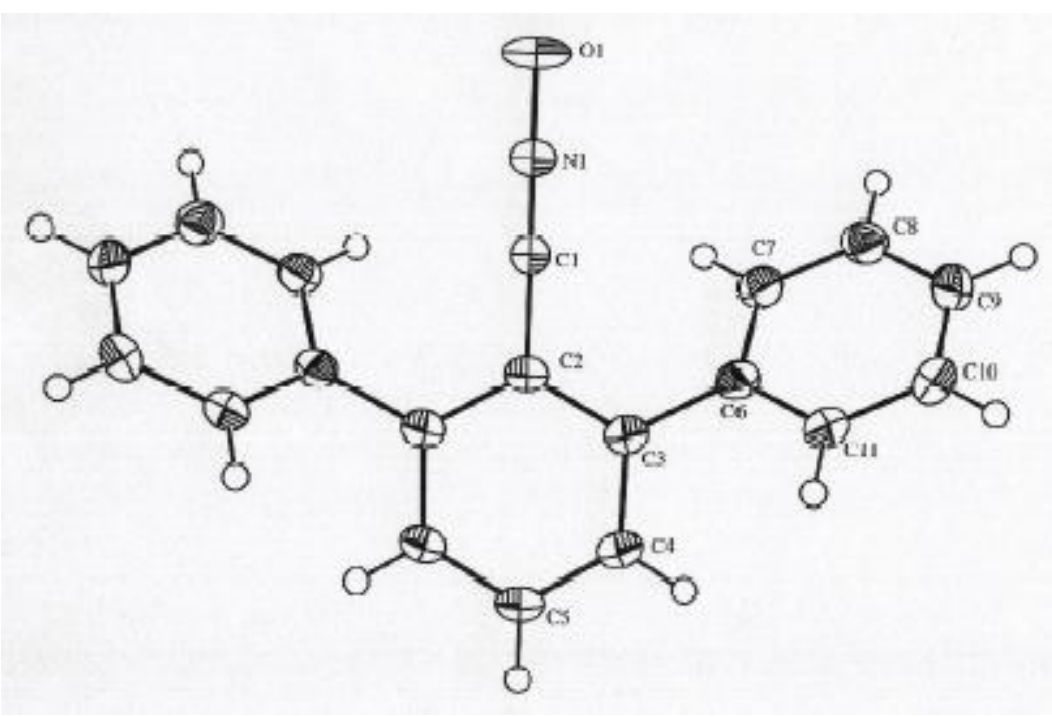

Figure 2

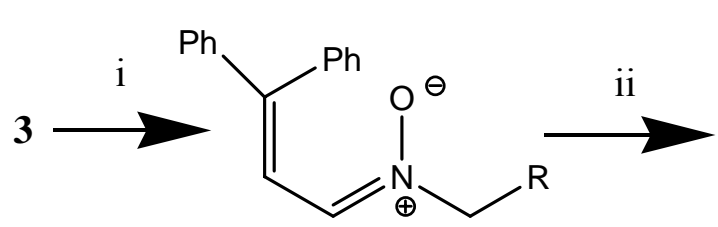

14a $\mathrm{R}=\mathrm{H}$

b $\mathrm{R}=\mathrm{Ph}$

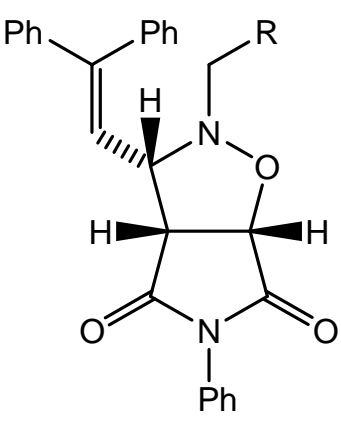

15a $\mathrm{R}=\mathrm{H}$

b $\mathrm{R}=\mathrm{Ph}$

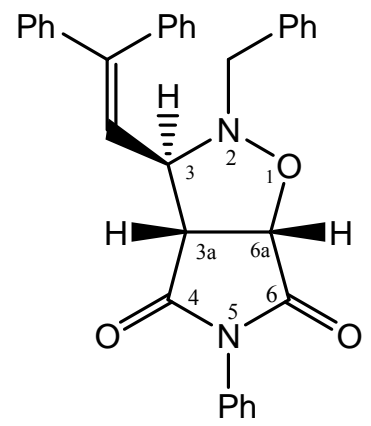

16

Scheme 3. Reagents and conditions; I, $\mathrm{RCH}_{2} \mathrm{NHOH}, \mathrm{Et}_{3} \mathrm{~N}, \mathrm{PhCH}_{3}$, reflux, 1h; ii, $\mathrm{N}$ phenylmaleimide, $\mathrm{PHCH}_{3}$, reflux.

Nitrones are easily available from aldehydes or ketones and $N$-monosubstituted hydroxylamines. In this manner -phenylcinnamaldehyde 3 was reacted with $N$-methyland $N$-benzylhydroxylamine, Scheme 3 . From both these reactions a stable, isolable nitrone 14a,b was formed and characterized (by elemental analysis or high resolution mass spectrometry). The stability of these nitrones is presumably also attributable to resonance stabilization. Although stable, these dipoles were easily trapped, in solution, by alkenic dipolarophiles in refluxing toluene, giving the corresponding cycloadducts 15 and 16. In the case of the $N$-methylnitrone this cycloaddition with $N$ phenylmaleimide was completely endo-selective giving $15 \mathrm{a}$, whilst the $N$-benzyl 
derivative gave a 1:1 mixture of endo- $15 \mathrm{~b}$ and exo-products 16 which were separated by crystallization.

The stereochemistry of the cycloadducts was deduced by n.O.e. experiments (Tables 1 and 2). The most important, decisive information obtained from these experiments is the presence / absence of the n.O.e. interaction between the $\mathrm{H}-3$ and $\mathrm{H}-3$ a protons in the endo- and exo-cycloadducts, respectively. The stereochemistry of the $N$-methyl adduct 15 a was assigned by comparison with the $N$-benzyl analogues.

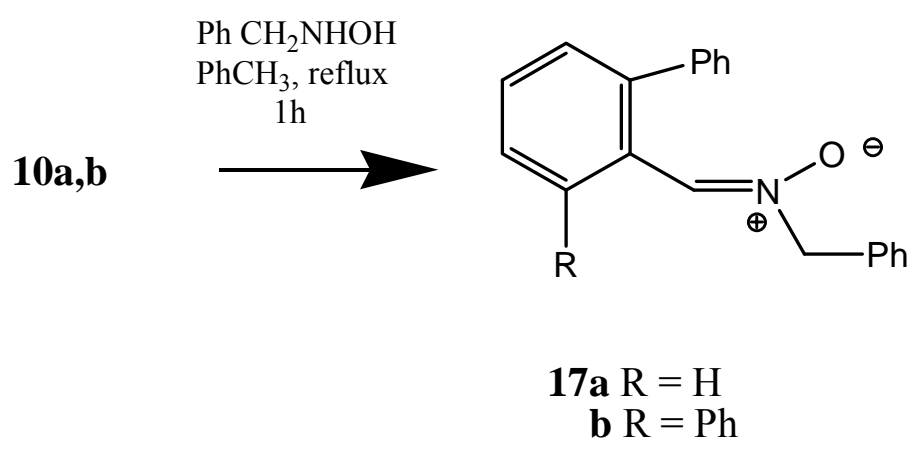

\section{Scheme 4}

The nitrones themselves proved to be remarkably stable upon refluxing in toluene or xylene. No 1,7-electrocyclisation reaction was observed, in contrast to other allylic dipoles, such as azomethine ${ }^{10}$ or carbonyl ylides, ${ }^{11}$ and only slow decomposition was observed after a few days reaction time.

\section{Experimental Section}

General Procedures. M.p.s were determined on a Gallenkamp apparatus and are uncorrected. Elemental analyses were performed on a Perkin-Elmer 240C or Carlo Erba 1106 Elemental Analyser. IR spectra were recorded on a Perkin-Elmer 1600 series FTIR or Unicam research series FTIR spectrophotometer using sodium chloride plates. ${ }^{1} \mathrm{H}$ NMR spectra were acquired on a Jeol GSX 270 FT NMR at $270 \mathrm{MHz}$, a Bruker AC 250 at $250 \mathrm{MHz}$, or a Bruker AVANCE 300 at 300MHz. Coupling constants are given in $\mathrm{Hz}$ and all chemical shifts are relative to an internal standard of tetramethylsilane. ${ }^{13} \mathrm{C}$ NMR spectra were obtained on a Jeol GFX 270 FT NMR (68 MHz) spectrometer or a Bruker AC 250 (63 MHz). Low resolution electron impact mass spectra were obtained on a Trio 2000 VG. High resolution spectra were obtained on a VG ZAB-E spectrometer (E.P.S.R.C. Mass Spectrometry Service Centre, Swansea) or Bruker 
APEX II ICR-MS. Thin layer chromatography was performed on Merck silica gel $60 \mathrm{~F}_{254}$. All solvents were purified according to standard procedures. Diethyl ether was freshly distilled over sodium wire with a trace of benzophenone. Toluene was distilled from, and stored over, sodium wire. Fisons silica gel 60 (35-70 micron) was used for wet flash chromatography. The samples were applied in liquid form or were preadsorbed onto silica 60 (35-70 micron) from dichloromethane solutions. 2Phenylbenzaldehyde and 2,6-diphenylbenzaldehyde were prepared by the method of Sharp and Cullen. ${ }^{12}$ 3,3-Diphenyl-2-propenaldoxime was prepared by the method of Lachman. ${ }^{8}$

\section{Crystal data for 2,6-diphenylbenzonitrile oxide (13b)}

$\mathrm{C}_{19} \mathrm{H}_{13} \mathrm{NO}, M=271.30$. Monoclinic, $a=9.839$ (2), $b=14.195$ (3), $c=10.0298$ (10) $\AA$, $\beta=96.989^{\circ}$ (10) (by least squares refinement of the setting angles for 2942 reflections within $\left.=2.50-26.30^{\circ}\right), \mathrm{V}=1390.3(4) \AA^{3}$, space group $\mathrm{P} 2(1) / \mathrm{m}, Z=4, D_{\mathrm{m}}=1.296 \mathrm{~g}$ $\mathrm{cm}^{-3} . \mathrm{F}(000)=568$. White crystals. Crystal dimensions $0.40 \times 0.35 \times 0.35 \mathrm{~mm},(\mathrm{Mo}-\mathrm{K})=$ $0.080 \mathrm{~mm}^{-1}$.

\section{Data collection and processing}

From the ranges scanned, 2942 data were collected $\left(2.5026 .30^{\circ}\right), 2942$ unique $\left(R_{\text {int }}=\right.$ $0.024)$.

\section{Structural analysis and refinement}

The structure was solved via direct methods (SHELX-S) ${ }^{13}$ and refined on $F_{\mathrm{o}}{ }^{2}$ by fullmatrix least-squares (SHELXL-93) ${ }^{14}$ using all unique data corrected for Lorentz and polarisation factors to final $w R$ (on $F_{\mathrm{o}}{ }^{2}$ ) and $R$ (on $F$ ) values of 0.1375 and 0.0651 for 205 parameters (non-hydrogen atoms anisotropic; hydrogens in idealised positions with $U_{\text {iso }}$ s tied to the $U_{\text {eq }} \mathrm{S}$ of the parents). The corresponding $R$-values for data with $\mathrm{I}>2 \mathrm{~s}(\mathrm{I})$ are 0.1276 and 0.0451 , respectively. The weighting scheme used was $w=1 /\left[\mathrm{s}^{2}\left(F_{\mathrm{o}}{ }^{2}\right)+\right.$ $\left.(0.0467 \mathrm{P})^{2}\right]$, where $\mathrm{P}=\left[\max \left(F_{\mathrm{o}}\right)^{2}+2\left(\mathrm{~F}_{\mathrm{c}}\right)^{2}\right] / 3$; this gave satisfactory agreement analyses. Sources of scattering factors as in ref. 14. Full details of data collection and structure refinements, atomic coordinates, bond lengths and angles and thermal parameters have been deposited at the Cambridge Crystallographic Data Centre.

\section{Isolation of nitrile oxides.General procedure}

To a solution of the oxime $(0.86 \mathrm{mmol})$ in dry DMF $\left(10 \mathrm{~cm}^{3}\right)$ was added $\mathrm{N}$ chlorosuccinimide $(0.86 \mathrm{mmol})$ in dry $\operatorname{DMF}\left(5 \mathrm{~cm}^{3}\right)$, dropwise, over $10-15 \mathrm{~min}$., at $40^{\circ} \mathrm{C}$. After stirring for $3 \mathrm{~h}$., the water bath was removed and the reaction mixture stirred at $25^{\circ} \mathrm{C}$, overnight. The reaction was quenched by pouring the mixture onto ice-water $\left(30 \mathrm{~cm}^{3}\right)$ and extracted with ether $\left(320 \mathrm{~cm}^{3}\right)$. The combined organic extracts were washed with ice-water $\left(10 \mathrm{~cm}^{3}\right)$ and brine solution $\left(10 \mathrm{~cm}^{3}\right)$, dried $\left(\mathrm{MgSO}_{4}\right)$ and solvent 
evaporated under reduced pressure to give a pale brown oil. The product was dissolved in ether $\left(6 \mathrm{~cm}^{3}\right)$ and a solution of triethylamine (1 equiv.) in ether $\left(3 \mathrm{~cm}^{3}\right)$ was added dropwise over $20 \mathrm{~min}$., at $0^{\circ} \mathrm{C}$. The mixture was stirred at $0^{\circ} \mathrm{C}$ for $1 \mathrm{~h}$. and allowed to reach room temperature overnight. The salt was filtered and the solvent removed under reduced pressure to give the nitrile oxide.

3,3-Diphenylpropenitrile oxide (6). From b-phenylcinnamaldehyde 3 asa pale brown oil (0.181 g, 94\%) (Found: $\mathrm{M}^{+}, 221.084$. Calc. for $\mathrm{C}_{15} \mathrm{H}_{11} \mathrm{NO}: M, 221.084$ ); $v_{\max }$ (liquid film) $/ \mathrm{cm}^{-1} 2287(\mathrm{CN}), 1598(\mathrm{C}=\mathrm{C})$; $\delta \mathrm{H}\left(270 \mathrm{MHz}, \mathrm{CDCl}_{3}\right) 5.76(1 \mathrm{H}, \mathrm{s}, \mathrm{C}=\mathrm{CH}), 7.17-$ 7.35 (10H, m, Ar-H); m/z 221 (M+1,90\%), 205 (100), 191 (38), 179 (28), 166 (61).

2-Phenylbenzonitrile oxide (13a). From 2-phenylbenzaldehyde 10a as a yellow oil (0.29g, 74\%) (Found: $\mathrm{MH}^{+}, 196.076$. Calc. for $\left.\mathrm{C}_{13} \mathrm{H}_{10} \mathrm{NO}: M H, 196.076\right) ; v_{\max }$ (liquid film) $/ \mathrm{cm}^{-1} 2296(\mathrm{CN}) ;{ }_{\delta \mathrm{H}}\left(270 \mathrm{MHz}, \mathrm{CDCl}_{3}\right)$ 7.15-7.50 (17H, m); m/z $196\left(\mathrm{MH}^{+}, 69 \%\right)$, 180 (63), and 178 (100).

2,6-Diphenylbenzonitrile oxide 13b. From 2,6-diphenylbenzaldehyde $10 \mathrm{~b}$ as white crystals (0.46 g, 79\%), mp 167-169C (Found: $\mathrm{MH}^{+}, 272.107$. Calc. for $\mathrm{C}_{19} \mathrm{H}_{14} \mathrm{NO}: \mathrm{MH}$, 272.1075); $v_{\max }$ (liquid film)/ $\mathrm{cm}^{-1} 2297(\mathrm{CN}) ; \delta \mathrm{H}\left(270 \mathrm{MHz}, \mathrm{CDCl}_{3}\right)$ 7.39-7.59 (13H, $\mathrm{m}) ; \mathrm{m} / \mathrm{z} 272(\mathrm{MH}+, 52 \%), 256(35)$ and 254 (100).

Trapping of 3,3-diphenylpropenitrile oxide 6

\section{Method 1}

$\mathrm{N}$-Chlorosuccinimide $(0.042 \mathrm{~g}, 0.31 \mathrm{mmol})$ was added to a solution of 3,3-diphenyl-2propenaldoxime $4(0.35 \mathrm{~g}, 1.57 \mathrm{mmol})$ in DMF $\left(24 \mathrm{~cm}^{3}\right)$, with stirring, under $\mathrm{N}_{2}$. The reaction was initiated by bubbling the gas from the head space of a concentrated $\mathrm{HCl}$ bottle through the solution. A further aliquot of $N$-chlorosuccinimide $(0.168 \mathrm{~g}, 1.25$ mmol) was then added, ensuring that the temperature remained below $35^{\circ} \mathrm{C}$. The reaction was again purged with $\mathrm{HCl}(\mathrm{g})$, then poured into 4 volumes of ice-water. The reaction mixture was extracted with ether $\left(310 \mathrm{~cm}^{3}\right)$. The combined ether extracts were washed with water $\left(30 \mathrm{~cm}^{3}\right)$, dried $\left(\mathrm{CaSO}_{4}\right)$ and evaporated under reduced pressure to give a dark brown oil $(0.29 \mathrm{~g}, 42 \%)$. This dark brown oil was purified by column chromatography on silica, eluting with ether / petroleum ether $40-60^{\circ} \mathrm{C}(0: 100$ to $10: 90)$, to give 3,6-bis(2',2'-diphenylethenyl)-1,4,2,5-dioxadiazine 7 as a pale brown oil $(0.17$ g, 49\%) (Found: $\mathrm{M}, 442.166$. Calc. for $\mathrm{C}_{30} \mathrm{H}_{22} \mathrm{~N}_{2} \mathrm{O}_{2}: M, 442.168$ ); $v_{\max }$ (liquid film) $/ \mathrm{cm}^{-1}$ $1650(\mathrm{C}=\mathrm{N}), 1599(\mathrm{C}=\mathrm{C}) ; \delta \mathrm{H}\left(360 \mathrm{MHz}, \mathrm{CDCl}_{3}\right) 6.49(2 \mathrm{H}, \mathrm{s}, \mathrm{C}=\mathrm{CH}), 7.02-7.36(20 \mathrm{H}$, $\mathrm{m}, \mathrm{Ar}-\mathrm{H}) ; \mathrm{m} / \mathrm{z} 442\left(\mathrm{M}^{+}, 7 \%\right), 221$ (100), 205 (60), 191 (79), and 179 (60).

\section{Method 2}

To a solution of 3,3-diphenyl-2-propenaldoxime 4 (0.18 g, $0.807 \mathrm{mmol})$ in DMF (3 $\left.\mathrm{cm}^{3}\right)$ was added $N$-chlorosuccinimide $(0.107 \mathrm{~g}, 0.807 \mathrm{mmol})$ in DMF $\left(2 \mathrm{~cm}^{3}\right)$, with stirring over ca. $10 \mathrm{~min}$., at $40^{\circ} \mathrm{C}$ under $\mathrm{N}_{2}$. The mixture was stirred for a further $1 \mathrm{~h}$., and allowed to reach room temperature overnight. The reaction mixture was poured onto ice 
$(11 \mathrm{~g})$ and extracted with ether $\left(315 \mathrm{~cm}^{3}\right)$. The combined organic extracts were washed with ice-cold water $\left(5 \mathrm{~cm}^{3}\right)$, brine solution $\left(3 \mathrm{~cm}^{3}\right)$, dried $\left(\mathrm{Na}_{2} \mathrm{SO}_{4}\right)$ and solvent evaporated under reduced pressure to give a brown oil $(0.16 \mathrm{~g})$. The crude oil was dissolved in dry ether $\left(5 \mathrm{~cm}^{3}\right)$ to which a solution of triethylamine $\left(0.11 \mathrm{~g}, 0.15 \mathrm{~cm}^{3}\right.$, $0.11 \mathrm{mmol})$ in ether $\left(5 \mathrm{~cm}^{3}\right)$ was added over ca. $20 \mathrm{~min}$., under $\mathrm{N}_{2}$. The mixture was stirred at room temperature and the precipitated salt filtered. The reaction was monitored by t.l.c., which showed a mixture of products. The filtrate was evaporated under reduced pressure to give a brown oil $(0.08 \mathrm{~g}, 22 \%)$. The oil was purified by column chromatography on silica, eluting with ether / petroleum ether $40-60^{\circ} \mathrm{C}(0: 100$ to 30:70), from which 3,4-bis(2',2'-diphenylethenyl)furoxan 8 was isolated as a pale brown oil (0.05 g, 28\%) (Found: $\mathrm{MH}^{+}$, 443.175. Calc. for $\mathrm{C}_{30} \mathrm{H}_{23} \mathrm{~N}_{2} \mathrm{O}_{2}: \mathrm{MH}^{+}, 443.175$ ); $\nu_{\max }$ (liquid film) $/ \mathrm{cm}^{-1} 1662(\mathrm{C}=\mathrm{N}), 1598(\mathrm{C}=\mathrm{C}) ; \delta \mathrm{H}\left(360 \mathrm{MHz}, \mathrm{CDCl}_{3}\right) 6.59(1 \mathrm{H}, \mathrm{s}$, $\mathrm{C}=\mathrm{CH}), 6.74(1 \mathrm{H}, \mathrm{s}, \mathrm{C}=\mathrm{CH}), 7.07-7.48(20 \mathrm{H}, \mathrm{m}, \mathrm{Ar}-\mathrm{H}) ; \mathrm{m} / \mathrm{z} 443\left(\mathrm{MH}^{+}, 6 \%\right), 425$ (42), 222 (100), 206 (94), and 180 (39); $\delta \mathrm{C}\left(68 \mathrm{MHz}, \mathrm{CDCl}_{3}\right), 110.1(\mathrm{CH}), 113.0(\mathrm{CH}), 128.4$ $(2 \times \mathrm{CH}), 128.5(2 \times \mathrm{CH}), 128.55(2 \times \mathrm{CH}), 128.6(2 \times \mathrm{CH}), 128.7(3 \times \mathrm{CH}), 128.75(3$ $\times \mathrm{CH}), 128.9(2 \times \mathrm{CH}), 129.15$ (quat.), 129.2 (quat.), $129.95(3 \times \mathrm{CH}), 130.0$ (quat.), 130.3 (quat.), 138.5 (quat.), 141.2 (quat.), 142.1 (quat.), 152 (quat.), 155.5 (quat.).

\section{Trapping of 3,3-diphenylpropenitrile oxide 6 with $\boldsymbol{N}$-phenylmaleimide}

To a solution of 3,3-diphenyl-2-propenaldoxime $4(0.0966 \mathrm{~g}, 0.433 \mathrm{mmol})$ in dry DMF $\left(10 \mathrm{~cm}^{3}\right)$ was added $N$-chlorosuccinimide in dry DMF $\left(5 \mathrm{~cm}^{3}\right)$, dropwise over 10 $15 \mathrm{~min}$., at $40^{\circ} \mathrm{C}$. After stirring for $3 \mathrm{~h}$., the water bath was removed and the reaction mixture allowed to stir at $25^{\circ} \mathrm{C}$, overnight. The reaction was quenched by pouring the mixture into ice $(10 \mathrm{~g})$ and extracted with ether $\left(320 \mathrm{~cm}^{3}\right)$. The combined organic extracts were washed with ice-water $\left(10 \mathrm{~cm}^{3}\right)$, brine solution $\left(10 \mathrm{~cm}^{3}\right)$, dried $\left(\mathrm{Na}_{2} \mathrm{SO}_{4}\right)$ and the solvent evaporated under reduced pressure to give a pale brown oil $(0.084 \mathrm{~g})$. The product was dissolved in ether $\left(6 \mathrm{~cm}^{3}\right)$ and $N$-phenylmaleimide $(0.056 \mathrm{~g}, 0.326$ mmol) added, with stirring, under $\mathrm{N}_{2}$. A solution of triethylamine $\left(0.065 \mathrm{~g}, 0.089 \mathrm{~cm}^{3}\right.$, $0.326 \mathrm{mmol})$ in ether $\left(3 \mathrm{~cm}^{3}\right)$ was added dropwise over $1 \mathrm{~h}$., at $0^{\circ} \mathrm{C}$ then the mixture was allowed to reach room temperature overnight. The precipitated solid was filtered and solvent evaporated under reduced pressure to give 4,6-dioxo-5-phenyl-3-(2,2diphenylethenyl)-2,5-diaza-1-oxabicyclo[3.3.0]octane 9 as a dark brown oil (0.152 g, $89 \%$ ). The dark brown oil was purified by wet flash column chromatography on silica, eluting with ethyl acetate / petroleum ether $60-80^{\circ} \mathrm{C}(0: 100$ to $20: 80)(0.149 \mathrm{~g}, 87 \%)$ (Found: $\mathrm{M}, 394.132$. Calc. for $\left.\mathrm{C}_{25} \mathrm{H}_{18} \mathrm{~N}_{2} \mathrm{O}_{3}: M, 394.132\right)$; $\delta \mathrm{H}\left(270 \mathrm{MHz}, \mathrm{CDCl}_{3}\right) 3.93$ $(1 \mathrm{H}, \mathrm{d}, J$ 9.8, H-3a), 5.27 (1H, d, J 9.9, H-6a), 6.82 (1H, s, H-3'), 7.18-7.38 (15H, m, Ar-H); $\delta \mathrm{C}\left(18 \mathrm{MHz}, \mathrm{CDCl}_{3}\right) 53.8(\mathrm{CH}), 79.4(\mathrm{CH}), 112.6(\mathrm{CH}), 128.1(6 \mathrm{xCH}), 128.5$ $(6 \times \mathrm{CH}), 129.2$ (4xCH), 130.6 (quat.), 138.9 (quat.), 140.8 (quat.), 152.3 (quat.), 152.7 
(quat.), 169.3 (quat., $\mathrm{C}=\mathrm{O}$ ), 170.7 (quat., $\mathrm{C}=\mathrm{O}) ; \mathrm{m} / \mathrm{z} 394\left(\mathrm{M}^{+}, 100 \%\right), 366$ (5), 247 (58), $205(60)$.

\section{General procedure for Isolation of nitrones.}

The aldehyde $(0.10 \mathrm{~g}, 0.48 \mathrm{mmol})$ and the $N$-substituted hydroxylamine $(0.48 \mathrm{mmol})$ were dissolved in dry toluene $\left(5 \mathrm{~cm}^{3}\right)$ and triethylamine $\left(0.07 \mathrm{~cm}^{3}, 0.05 \mathrm{~g}, 0.5 \mathrm{mmol}\right)$ was added. The reaction mixture was refluxed for one hour under Dean and Stark conditions and an argon atmosphere. After cooling, the precipitated triethylamine hydrochloride was filtered off, and the solution was evaporated. The residue was triturated with ether to give the product.

$\boldsymbol{N}$-Methyl- $\boldsymbol{N}$-(3,3-diphenylpropenyl)nitrone (14a). From $\beta$-phenylcinnamaldehyde 3 and $N$-methylhydroxylamineas awhite powder, $\mathrm{mp} 148-150{ }^{\circ} \mathrm{C}(90 \mathrm{mg}, 79 \%)$ ) (Found: C, 80.9; H, 6.3; N, 5.9. $\mathrm{C}_{16} \mathrm{H}_{15} \mathrm{NO}$ requires $\mathrm{C}, 81.0 ; \mathrm{H}, 6.4 ; \mathrm{N}, 5.9 \%$ ) (Found: $\mathrm{MH}^{+}$, 238.122. Calc. for $\mathrm{C}_{16} \mathrm{H}_{16} \mathrm{NO}: \mathrm{MH}, 238.123$. Found: $\mathrm{MNa}^{+}, 260.1045$. Calc. for $\left.\mathrm{C}_{16} \mathrm{H}_{15} \mathrm{NONa}: M N a, 260.105\right) ; \delta \mathrm{H}\left(250 \mathrm{MHz}, \mathrm{CDCl}_{3}\right) 3.66(3 \mathrm{H}, \mathrm{s}, \mathrm{Me}), 7.04(1 \mathrm{H}, \mathrm{d}, J$ 9.5), 7.19-7.27 (2H, m), 7.27-7.38 (5H, m), 7.39-7.48 (4H, m); $\delta \mathrm{C}\left(63 \mathrm{MHz}, \mathrm{CDCl}_{3}\right)$ $52.7\left(\mathrm{CH}_{3}\right), 117.4(\mathrm{CH}), 128.2(2 \mathrm{CH}), 128.5(2 \mathrm{CH}), 128.6(\mathrm{CH}), 128.7(2 \mathrm{CH}), 129.0$ (quat.), $130.2(2 \mathrm{CH}), 136.7(\mathrm{CH}), 138.7$ (quat.), 140.7 (quat.), 149.6 (quat.); $v_{\max }$ $(\mathrm{KBr}) / \mathrm{cm}^{-1} 1540(\mathrm{C}=\mathrm{C}) ; \mathrm{m} / \mathrm{z} 238\left(\mathrm{M}^{+}, 100\right), 222$ (29), 209 (13), 181 (4), 144 (3), 107 (4), 85 (10), 71 (9), and 57 (26).

$\boldsymbol{N}$-Benzyl- $\boldsymbol{N}$-(3,3-diphenylpropenyl)nitrone (14b). From $\beta$-phenylcinnamaldehyde 3 and $\mathrm{N}$-benzylhydroxylamineas awhite powder, $\mathrm{mp} 120-2{ }^{\circ} \mathrm{C}(110 \mathrm{mg}, 71 \%)$ (Found: $\mathrm{MH}^{+}, 314.154$. Calc. for $\mathrm{C}_{22} \mathrm{H}_{20} \mathrm{NO}: \mathrm{MH}, 314.154$. Found: $\mathrm{MNa}^{+}, 336.136$. Calc. for $\left.\mathrm{C}_{22} \mathrm{H}_{20} \mathrm{NONa}: M N a, 336.136\right) ; \delta \mathrm{H}\left(250 \mathrm{MHz}, \mathrm{CDCl}_{3}\right) 4.86\left(2 \mathrm{H}, \mathrm{s}, \mathrm{CH}_{2}\right), 7.08(1 \mathrm{H}, \mathrm{d}$, J10), 7.19-7.13 (2H, m), 7.27-7.43 (14H, m); $\delta \mathrm{C}\left(63 \mathrm{MHz}, \mathrm{CDCl}_{3}\right) 69.6\left(\mathrm{CH}_{2}\right), 117.5$ $(\mathrm{CH}), 128.3(2 \mathrm{CH}), 128.5(2 \mathrm{CH}), 128.6(3 \mathrm{CH}), 128.9$ (quat.), $129.0(3 \mathrm{CH}), 129.2(2$ $\mathrm{CH}), 130.3(2 \mathrm{CH}), 133.4(\mathrm{CH}), 135.8$ (quat.), 138.8 (quat.), 140.8 (quat.), $149.9(\mathrm{CH})$; $v_{\max }(\mathrm{KBr}) / \mathrm{cm}^{-1} 1684(\mathrm{C}=\mathrm{C}), 1540(\mathrm{C}=\mathrm{C}) ; \mathrm{m} / \mathrm{z} 314\left(7 \%, \mathrm{M}^{+}\right), 250$ (7), 237 (18), 222 (28), 209 (100), 146 (5), 134 (14), 106 (67), 85 (27), 71 (23), and 57 (78).

$\boldsymbol{N}$-Benzyl- $\boldsymbol{N}$-(2-phenylbenzylidene)nitrone (17a). From 2-phenylbenzaldehyde 10a and $\mathrm{N}$-benzylhydroxylamineas ayellow oil $(0.28 \mathrm{~g}, 65 \%)$ (Found: $\mathrm{MH}^{+}, 314.154$. Calc. for $\mathrm{C}_{20} \mathrm{H}_{18} \mathrm{NO}$ : $M H, 314.154$. Found: $\mathrm{MNa}^{+}, 310.120$. Calc. for $\mathrm{C}_{20} \mathrm{H}_{17} \mathrm{NONa}$ : $M N a$, 310.120); $\delta \mathrm{H}\left(270 \mathrm{MHz}, \mathrm{CDCl}_{3}\right) 4.72\left(2 \mathrm{H}, \mathrm{s}, \mathrm{CH}_{2}\right), 7.05-7.29(14 \mathrm{H}, \mathrm{m}), 9.32(1 \mathrm{H}, \mathrm{m}) ; \delta \mathrm{C}$ $\left(68 \mathrm{MHz}, \mathrm{CDCl}_{3}\right) 70.7\left(\mathrm{CH}_{2}\right), 126.8(\mathrm{CH}), 126.9(\mathrm{CH}), 127.1(\mathrm{CH}), 127.2(\mathrm{CH}), 127.7$ $(2 \mathrm{xCH}), 128.0(\mathrm{CH}), 128.1(2 \mathrm{xCH}), 128.5(2 \mathrm{xCH}), 128.9$ (quat.), $129.1(2 \mathrm{x} \mathrm{CH})$, $129.15(\mathrm{CH}), 131.7(\mathrm{CH}), 132.6$ (quat.), 139.0 (quat.), 141.2 (quat.); $v_{\max }(\mathrm{KBr}) / \mathrm{cm}^{-1}$ 1576, $1555(\mathrm{C}=\mathrm{C})$.

$\boldsymbol{N}$-Benzyl- $\boldsymbol{N}$-(2,6-diphenylbenzylidene)nitrone (17b). $\quad$ From 2,6diphenylbenzaldehyde $10 \mathrm{~b}$ and $N$-benzylhydroxylamineas awhite solid after trituration 
with ether, mp $176-178^{\circ} \mathrm{C}(0.44 \mathrm{~g}, 81 \%)$ (Found: $\mathrm{MH}^{+}, 364.169$. Calc. for $\mathrm{C}_{26} \mathrm{H}_{22} \mathrm{NO}$ : $M H, 364.170$. Found: $\mathrm{MNa}^{+}, 386.1515$. Calc. for $\left.\mathrm{C}_{26} \mathrm{H}_{21} \mathrm{NONa}: M N a, 386.152\right) ;{ }_{\delta \mathrm{H}}(270$ $\left.\mathrm{MHz} \mathrm{CDCl}_{3}\right) 4.55$ (2H,s, $\left.\mathrm{CH}_{2}\right)$, 7.04-7.47 (19H, m); $\delta \mathrm{C}\left(68 \mathrm{MHz}, \mathrm{CDCl}_{3}\right)$ 69.4, 127.0, $127.3(2 \mathrm{x} \mathrm{CH}), 128.0(4 \mathrm{xCH}), 128.05(4 \mathrm{xCH}), 128.6(2 \times \mathrm{CH}), 128.9(2 \times \mathrm{CH}), 129.2$, $129.5(2 \times C H), 132.15,134.2(2 x C H), 140.85(2 x C H), 142.6(2 x \mathrm{CH}) ; v_{\max }(\mathrm{KBr}) / \mathrm{cm}^{-1}$ $1649(\mathrm{C}=\mathrm{C}) ; \mathrm{m} / \mathrm{z} 364\left(\mathrm{MH}^{+}, 100 \%\right), 348$ (39), 259 (8), and 241 (18).

\section{General procedure for the trapping of nitrones with $\boldsymbol{N}$-phenylmaleimide}

The nitrone $(0.38 \mathrm{mmol})$ and $N$-phenylmaleimide $(70 \mathrm{mg}, 0.40 \mathrm{mmol})$ were dissolved in toluene $\left(5 \mathrm{~cm}^{3}\right)$ and the solution was refluxed for 3 hours. The solvent was removed and the residue was purified by column chromatography and / or recrystallization [from hexane - ethyl acetate $(3: 1)]$.

2-Methyl-4,6-dioxo-5-phenyl-3-(2',2'-diphenylethenyl)-2,5-diaza-1-oxabicyclo-

[3.3.0] octane 15a. From $N$-methyl- $N$-(3,3-diphenylpropenyl)nitrone $14 \mathrm{a}$ and $N$ phenylmaleimide as a pale yellow oil after column chromatography (70 $\mathrm{mg}, 45 \%$ ) (Found: $\mathrm{C}, 74.8 ; \mathrm{H}, 5.4 ; \mathrm{N}, 6.9 . \mathrm{C}_{26} \mathrm{H}_{22} \mathrm{~N}_{2} \mathrm{O}_{3} .1 / 2 \mathrm{H}_{2} \mathrm{O}$ requires $\mathrm{C}, 74.5 ; \mathrm{H}, 5.5 ; \mathrm{N}, 6.7 \%$ ) (Found: $\mathrm{MH}^{+}, 411.170$. Calc. for $\mathrm{C}_{26} \mathrm{H}_{23} \mathrm{~N}_{2} \mathrm{O}_{3}$ : $\mathrm{MH}, 411.170$. Found: $\mathrm{MNa}^{+}, 433.152$. Calc. for $\left.\mathrm{C}_{26} \mathrm{H}_{22} \mathrm{~N}_{2} \mathrm{O}_{3} \mathrm{Na}: M N a, 433.152\right) ;{ }_{\delta \mathrm{H}}\left(250 \mathrm{MHz}, \mathrm{CDCl}_{3}\right) 2.66\left(3 \mathrm{H}, \mathrm{s}, \mathrm{N}-\mathrm{CH}_{3}\right)$, $3.43(1 \mathrm{H}, \mathrm{dd}, J 7.6$ and 7.2, $\mathrm{H}-3 a), 3.51(1 \mathrm{H}, \mathrm{dd}, J 9.5$ and $7.6, \mathrm{H}-3), 4.84(1 \mathrm{H}, \mathrm{d}, J 7.2$, H-6a), 5.82 (1H, d, J 9.5, H-3'), 7.22 - 7.53 (15H, m, Ar-H); $\delta \mathrm{C}\left(63 \mathrm{MHz}, \mathrm{CDCl}_{3}\right) 42.3$ $\left(\mathrm{CH}_{3}\right), 53.0(\mathrm{CH}), 70.5(\mathrm{CH}), 75.9(\mathrm{CH}), 126.2(\mathrm{CH}), 126.3(2 \times \mathrm{CH}), 127.5(2 \times \mathrm{CH})$, $127.8(\mathrm{CH}), 128.3(2 \times \mathrm{CH}), 128.6(2 \times \mathrm{CH}), 128.8(\mathrm{CH}), 129.1\left(2^{\prime} \mathrm{CH}\right), 129.2(2 \mathrm{x} \mathrm{CH})$, $129.7(\mathrm{CH}), 131.5$ (quat.), 139.2 (quat.), 140.9 (quat.), 148.6 (quat.), $172.5(\mathrm{C}=\mathrm{O})$, $174.6(\mathrm{C}=\mathrm{O})$.

\section{2-benzyl-4,6-dioxo-5-phenyl-3-(2',2'-diphenylethenyl)-2,5-diaza-1-oxabicyclo-}

[3.3.0]octane 15b, 16. From $N$-benzyl- $N$-(3,3-diphenylpropenyl)nitrone (14b) and $N$ phenylmaleimide. exo adduct 16; white powder, recrystallised after column chromatography, mp 129-132 ${ }^{\circ} \mathrm{C}\left(30 \mathrm{mg}, 19 \%\right.$ ) (Found: $\mathrm{MH}^{+}, 487.202$. Calc. for $\left.\mathrm{C}_{32} \mathrm{H}_{27} \mathrm{~N}_{2} \mathrm{O}_{3}: M H, 487.202\right)$; ${ }_{8 \mathrm{H}}\left(250 \mathrm{MHz}, \mathrm{CDCl}_{3}\right) 3.74(1 \mathrm{H}, \mathrm{dd}, J 7.3$ and 2.1, H-3a), $3.87\left(1 \mathrm{H}, \mathrm{d}, J\right.$ 13.9, $\left.\mathrm{PhCH}_{2}\right), 4.22\left(2 \mathrm{H}, \mathrm{m}, \mathrm{PhCH}_{2}\right.$ and $\left.\mathrm{H}-3 a\right), 4.99(1 \mathrm{H}, \mathrm{d}, J$ 7.3, H-6a), 6.34 (1H, d, J 9.9, H-3'), 7.10 - 7.55 (20H, m, Ar-H); $\delta \mathrm{C}\left(63 \mathrm{MHz}, \mathrm{CDCl}_{3}\right) 55.1(\mathrm{CH})$, $56.2\left(\mathrm{CH}_{2}\right), 66.1(\mathrm{CH}), 75.7(\mathrm{CH}), 122.3(\mathrm{CH}), 126.3(\mathrm{CH}), 126.6(\mathrm{CH}), 127.4(\mathrm{CH})$, $127.6(\mathrm{CH}), 127.9(\mathrm{CH}), 128.4(\mathrm{CH}), 128.9(\mathrm{CH}), 129.2(\mathrm{CH}), 129.8(\mathrm{CH}), 131.4$ (quat.), 136.2 (quat.), 137.9 (quat.), 141.3 (quat.), 147.6 (quat.), $165.8(\mathrm{C}=\mathrm{O}), 173.8$ $(\mathrm{C}=\mathrm{O})$.

endo adduct 15b. white powder recrystallised after column chromatography, mp 138$140{ }^{\circ} \mathrm{C}\left(80 \mathrm{mg}, 52 \%\right.$ ) (Found: $\mathrm{C}, 78.5 ; \mathrm{H}, 5.4 ; \mathrm{N}, 5.7 . \mathrm{C}_{32} \mathrm{H}_{26} \mathrm{~N}_{2} \mathrm{O}_{3}$ requires $\mathrm{C}, 79.0 ; \mathrm{H}$, 5.4; N, 5.75\%) (Found: $\mathrm{MH}^{+}$, 487.202. Calc. for $\mathrm{C}_{32} \mathrm{H}_{27} \mathrm{~N}_{2} \mathrm{O}_{3}: M H, 487.202$. Found: 
$\mathrm{MNa}^{+}$, 509.184. Calc. for $\left.\mathrm{C}_{32} \mathrm{H}_{26} \mathrm{~N}_{2} \mathrm{O}_{3} \mathrm{Na}: M N a, 509.184\right) ;{ }_{\delta \mathrm{H}}\left(250 \mathrm{MHz}, \mathrm{CDCl}_{3}\right) 3.54$ (1H, t, J 7.5, H-3a), 3.66 (1H, dd, J 9.4 and 7.7, H-3), 3.79 (1H, d, J 14.9, $\left.\mathrm{PhCH}_{2}\right), 4.20$ $\left(1 \mathrm{H}, \mathrm{d}, J\right.$ 14.9, $\left.\mathrm{PhCH}_{2}\right), 4.85$ (1H, d, J 7.5, H-6a), 5.79 (1H, d, J 9.4, H-3'), 7.15 - 7.48 $(20 \mathrm{H}, \mathrm{m}, \mathrm{Ar}-\mathrm{H})$; $\delta \mathrm{c}\left(63 \mathrm{MHz}, \mathrm{CDCl}_{3}\right) 52.9(\mathrm{CH}), 58.5\left(\mathrm{CH}_{2}\right), 68.4(\mathrm{CH}), 76.0(\mathrm{CH})$, $120.4(\mathrm{CH}), 126.0(\mathrm{CH}), 126.3(2 \times \mathrm{CH}), 127.6(2 \times \mathrm{CH}), 127.9(\mathrm{q}), 128.0(\mathrm{CH}), 128.1$ $(\mathrm{CH}), 128.2(2 \mathrm{xCH}), 128.3(2 \mathrm{xCH}), 128.4(2 \mathrm{xCH}), 128.6(2 \mathrm{xCH}), 129.1(\mathrm{CH}), 129.2$ $(2 \times \mathrm{CH}), 131.5(\mathrm{CH}), 134.2(\mathrm{CH}), 136.0$ (quat.), 139.3 (quat.), 140.9 (quat.), 148.0 (quat.), $172.3(\mathrm{C}=\mathrm{O}), 174.1(\mathrm{C}=\mathrm{O})$.

\section{Acknowledgements}

We thank the EPSRC for a studentship (T.S.), the University of Sunderland for funding (W.Z.), the Royal Society / NATO for a fellowship (M.N.), and the EPSRC National Mass Spectrometry Service Centre, Swansea for high resolution mass spectra.

\section{References}

1. (a) DeSarlo, F. J. Chem. Soc., Perkin Trans. I, 1974, 1951. (b) Grundmann, Ch.; Grunanger P. The Nitrile Oxides; Springer-Verlag: Berlin, 1971; p 242.

2. (a) Shiro, M.; Yamakawa, M.; Kubota, T. Acta Crystallogr. 1979, B35, 712. (b) Shiro, M.; Yamakawa, M.; Kubota, T.; Koyama, H. J. Chem. Soc., Chem. Commun. 1968, 1409.

3. Krayushkin, M. M.; Vorontsova, L. G.; Kurella, M. G.; Kalik, M. A. Russ. Chem. Bull. 1993, 42, 689.

4. Confalone, P. N.; Huie, E. M. Org. React. 1988, 36, 1; Torsell, K. B. G. Nitrile Oxides, Nitrones and Nitronates in Organic Synthesis; H. Feuer Ed.; VCH Publishers: New York, 1988.

5. Bloch, R. Chem. Rev. 1998, 98, 1407.

6. Fevig, T. L.; Bowen, S. M.; Janowick, D. A.; Jones, B. K.; Munson, H. R.; Ohlweiler, D. F.; Thomas, C. E. J. Med. Chem. 1996, 39, 4988.

7. Eberbach, W.; Roser, J. Tetrahedron Lett. 1987, 28, 2689.

8. Lachman, Org. Synth; Coll: 1943; Vol. 2, p 70.

9. Liu, K.-C.; Shelton, B. R.; Howe, R. K. J. Org. Chem. 1980, 45, 3916.

10. (a) Groundwater, P. W.; Nyerges, M. Adv. Het. Chem. 1999, 73, 97. (b) Arany, A.; Bendell, D.; Groundwater, P. W.; Garnett, I.; Nyerges, M. J. Chem. Soc. Perkin Trans. 1, 1999, 2605. 
11. Eberbach, W.; Buchardt, B.; Trostmann, U. Tetrahedron Lett. 1979, 19, 4049. (b) O’Shea, D. F.; Sharp, J. T. J. Chem. Soc. Perkin Trans. 1, 1997, 3025.

12. Cullen, K. E.; Sharp, J. T. J. Chem.Soc., Perkin Trans. I, 1993, 2961.

13. Sheldrick, G. M. Acta Crystallogr. Sect. A, 1990, 46, 467.

14. Sheldrick, G. M. SHELXL-93: Program for Crystal Structure Refinement; University of Göttingen: Germany. 